\title{
MENCARI MINIMUM SPANNING TREE DENGAN KONSTREN
}

\author{
MIFTAHUL JANNAH, NARWEN, BUKTI GINTING \\ Program Studi Matematika, \\ Fakultas Matematika dan Ilmu Pengetahuan Alam, Universitas Andalas, \\ Kampus UNAND Limau Manis Padang, Indonesia. \\ email : miftahulj1003@gmail.com
}

\begin{abstract}
Abstrak. Misalkan $G=(V, E)$ adalah graf tak berarah terhubung yang bukan tree, berarti di $G$ terdapat cycle. Dengan cyclic interchange maka diperoleh subgraf $T$ yang tidak memuat cycle. Subgraf $T$ inilah yang dinamakan dengan spanning tree. Minimum spanning tree adalah spanning tree dengan jumlah bobot terkecil. Pada skripsi ini akan dibahas tentang bagaimana menentukan minimum spanning tree dengan konstren dari suatu graf terhubung sederhana.
\end{abstract}

Kata Kunci: Spanning tree, Minimum spanning tree, Spanning tree dengan konstren

$\begin{array}{lll}\text { Diterima } & : & 29 \text { November } 2018 \\ \text { Direvisi } & : & 3 \text { Desember } 2018 \\ \text { Dipublikasikan } & : & 30 \text { Desember } 2018\end{array}$

\section{Pendahuluan}

Misalkan ada seorang pedagang keliling yang berjualan keliling di lima sekolah berbeda disuatu kota. Akan dicari rute terpendek yang bisa dilalui oleh pedagang keliling tersebut jika pedagang itu berangkat dari sebuah sekolah. Setiap sekolah dihubungkan oleh satu rute. Model matematika yang dapat digunakan dalam masalah ini adalah graf berbobot (weighted graph).

Graf berbobot adalah graf yang setiap sisinya diberi sebuah harga (bobot). Bobot pada sisi dapat berbeda-beda tergantung pada masalah yang dimodelkan dengan graf. Dalam masalah ini bobot sisi mewakili jarak antara dua sekolah, sisisisi mewakili rute yang dilalui dan titik-titik mewakili setiap sekolah.

Karena suatu alasan, ada beberapa rute yang menghubungkan setiap dua sekolah yang pasti dilalui oleh pedagang keliling tersebut. Permasalahan tersebut dapat diselesaikan dengan mencari semua spanning tree yang mempunyai penjumlahan bobot sisi minimum. Rute yang pasti dilalui dianggap sebagai konstren, konstren adalah sisi yang harus ada disetiap spanning tree yang akan dicari penjumlahan bobot sisinya.

Masalah selanjutnya adalah berapa banyak minimum spanning tree dengan konstren yang dapat dibentuk dan sisi mana saja dari graf tersebut yang membentuk minimum spanning tree dengan mempertahankan sisi-sisi tertentu sebagai konstren. 


\section{Tinjauan Teori}

Suatu graf adalah himpunan titik-titik yang terhubung oleh sisi-sisi. Suatu graf $G=(V, E)$ terdiri dari himpunan hingga titik-titik (verices) dan himpunan sisi-sisi (edges) yang menghubungkan pasangan titik yang berbeda.

Tree adalah graf tak-berarah terhubung yang tidak mengandung sirkuit (cycle).

Misalkan $G=(V, E)$ adalah graf tak berarah terhubung yang bukan tree, berarti di $G$ terdapat cycle. Dengan cyclic interchange maka diperoleh subgraf $T$ yang tidak memuat cycle. Subgraf $T$ inilah yang dinamakan dengan spanning tree. Spanning tree $T$ memuat semua titik di $G$, dan semua sisi di $T$ merupakan sisi pada graf $G$.

Jika $G$ adalah graf terhubung dan berbobot, maka bobot spanning tree $T$ dari $G$ didefinisikan sebagai jumlah semua bobot sisi di $T$ atau $\sum w(e), \forall e \in T$. Untuk spanning tree yang berbeda dalam graf $G$ secara umum akan mempunyai bobot yang berbeda, tapi diantara semua spanning tree tersebut pasti ada yang mempunyai jumlah bobot sisi terkecil. Spanning tree ini dikenal dengan sebutan minimum spanning tree (MST).

\subsection{Matriks Representasi Graf}

(1) Matriks representasi graf tanpa Pembobotan.

(a) Matriks ketetanggaan (Adjacency Matriks).

Matriks ketetanggaan adalah representasi graf yang paling umum. Misalkan $G=(V, E)$ adalah graf dengan $n$ titik, $n \geq 1$. Misalkan matriks ketetanggaan dari graf $G$ adalah matriks $X=\left[x_{i j}\right]$ berukuran $n \times n$ yang entri-entrinya adalah

$x_{i j}=\left\{\begin{array}{l}1, \quad \text { jika titik } i \text { dan } j \text { bertetangga; } \\ 0, \text { jika titik } i \text { dan } j \text { tidak bertetangga. }\end{array}\right.$

(b) Matriks Bersisian (Incidence Matriks).

Matriks bersisian menyatakan kebersisian titik dengan sisi. Misalkan $G=$ $(V, E)$ adalah graf dengan $n$ titik dan $m$ sisi. Matriks bersisian $G$ adalah matriks berukuran $n \times m$. Baris menunjukkan label titik dan kolom menunjukkan label sisinya. Misalkan matriks bersisian dari graf berarah $G$ adalah matriks $D=\left[x_{i j}\right]$ berukuran $n \times m$ yang entri-entrinya adalah

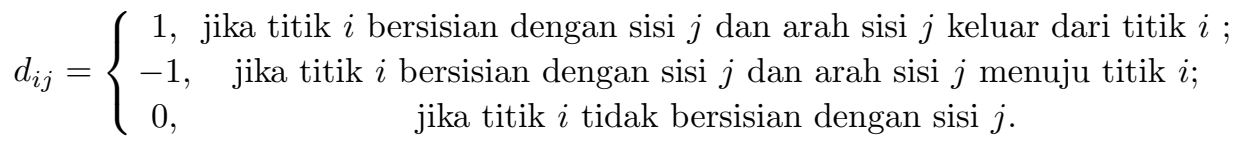

(2) Matriks representasi graf dengan Pembobotan

Graf $G=(V, E)$ dikatakan graf dengan pembobotan, apabila ada fungsi bobot $w$ bernilai positif pada sisi-sisi dari graf $G$. Jadi $w\left(e_{i j}\right)$ adalah bobot sisi antara titik ke- $i$ dan titik ke- $j[6]$.

\section{(a) Matriks bobot sisi}

Matriks bobot sisi dari graf $G$ dengan pembobotan adalah matriks $X=\left[x_{i j}\right]_{n \times n}$ yang entri-entrinya adalah

$x_{i j}=\left\{\begin{array}{c}w\left(e_{i j}\right), \quad \text { jika } w\left(e_{i j}\right) \text { bobot sisi antara titik ke- } i \text { dan titik ke- } j ; \\ 0, \quad \text { jika tidak ada sisi yang menghubungkan titik ke- } i \text { dan titik ke- } j .\end{array}\right.$ 
(b) Insidensi bobot sisi

Misalkan pada graf berbobot $G$ diberikan arah sebarang, titik-titik diberi nomor $i=1,2,3, \cdots, n$ dan sisi-sisi diberi nomor $j=1,2,3, \cdots, b$, maka matriks insidensi bobot sisi dari graf $G$ adalah matriks $D=\left[d_{i j}\right]_{n \times b}$ yang entri-entrinya adalah

$$
d_{i j}=\left\{\begin{array}{c}
w\left(e_{i j}\right), \quad \text { jika sisi ke- } j \text { arahnya keluar dari titik ke- } i, \\
-w\left(e_{i j}\right), \quad \text { jika sisi ke- } j \text { arahnya menuju titik ke- } i, \\
0, \quad \text { jika sisi ke- } j \text { tidak menempel pada titik ke- } i
\end{array}\right.
$$

Matriks insidensi bobot sisi ini diperoleh dengan merubah matriks insidensi, yaitu \pm 1 diganti dengan $\pm w\left(e_{i j}\right)$. Dengan menghapus salah satu baris sebarang dari matriks insidensi bobot sisi $D$ diperoleh matriks insidensi bobot sisi tereduksi yang dilambangkan dengan $A$.

\subsection{Determinan Matriks}

Matriks adalah susunan segi empat siku-siku dari bilangan-bilangan yang diatur dalam baris dan kolom. Bilangan tresebut dinamakan entri dari matriks. Misalkan suatu matriks mempunyai $n$ baris dan $m$ kolom, maka matriks tersebut adalah mariks berukuran $n \times m$. Matriks dengan ukuran $n \times n$ dinamakan matriks bujursangkar. Matriks yang mempunyai determinan adalah matriks bujursangkar.

Definisi 2.1. [2] Suatu hasilkali elementer (elementary product) dari suatu matriks $A, n \times n$, adalah hasilkali dari $n$ entri dari $A$, yang tidak satupun berasal dari baris atau kolom yang sama.

Determinan matriks $A$ bisa $\operatorname{ditulis} \operatorname{det}(A)$ atau $|A|$.

\section{Minimum Spanning Tree}

Suatu himpunan $H$ dari $n-1$ sisi dari graf $G$ dengan pembobotan merupakan spanning tree jika dan hanya jika $\operatorname{det} M(H) \neq 0$, dimana $M(H)$ adalah submatriks berukuran $(n-1) \times(n-1)$ dari matriks insidensi bobot sisi tereduksi $A$ yang kolom-kolomnya berkorespondensi dengan sisi-sisi $H$. Dengan demikian jelaslah bahwa untuk sebarang spanning tree $H$, det $M(H)= \pm \prod e_{i}$ dimana $e_{i} \in H, i=1,2, \cdots, n-1$. Determinan ini dapat digunakan untuk mengidentifikasi minimum spanning tree yang terdapat didalam graf $G$ [6].

Teorema 3.1. [8] Suatu spanning tree dalam graf $G$ dengan pembobotan mempuñyai penjumlahan bobot sisi yang minimum jika dan hanya jika spanning tree tersebut mempunyai perkalian bobot sisi yang minimum.

Bukti. $(\Leftarrow)$ Misalkan $S$ dan $T$ adalah spanning tree dari graf $G$. Andaikan $T$ mempunyai perkalian bobot sisi minimum tetapi bukan penjumlahan bobot sisi minimum. Misalkan $S$ sebuah tree dengan penjumlahan bobot sisi minimum. Maka spektrum bobot sisi dari $T$ dan $S$ tidak sama. Misalkan $k$ bobot sisi terkecil sehingga untuk semua sisi yang bobotnya lebih besar atau sama dengan $k$ maka $T$ 
dan $S$ mempunyai spektrum bobot sisi tidak sama. Akibatnya, $T$ mempunyai lebih kecil atau sama banyak sisi yang bobotnya $k$ dari pada $S$. Jadi haruslah $T$ mempunyai lebih kecil atau sama banyaknya sisi bobot nya $k$ dari pada $S$. Misalkan $T(k)$ adalah himpunan sisi-sisi $T$ bobotnya lebih kecil atau sama dengan $k$. Dalam hal ini, anggota $T(k)$ dapat dipilih semuanya dengan menggunakan algoritma kruskal. Karena spektrum dari sisi yang bobotnya $k$ belum digunakan semuanya , maka paling sedikit ada satu sisi $e \in G$ yang bobotnya $k$ tidak membentuk cycle dengan $T(k)$. Sisi $e$ yang demikian akan membentuk sebuah cycle dengan $T$. Karena itu, ada beberapa sisi pada cycle tersebut yang bobotnya lebih besar dari pada bobot sisi $e$. Ganti sisi bobot nya lebih besar dari bobot $e$ dengan sisi $e$, sehingga diperoleh sebuah tree dengan perkalian bobot sisi lebih kecil dari perkalian bobot sisi $T$. Hal ini kontradiksi dengan hipotesis bahwa $T$ merupakan perkalian bobot sisi minimum. Jadi jika $T$ mempunyai perkalian bobot sisi minimum, maka $T$ mempunyai penjumlahan bobot sisi minimum.

$(\Rightarrow$ ) Andaikan $T$ mempunyai penjumlahan bobot sisi minimum tetapi bukan perkalian bobot sisi minimum. Misalkan $S$ sebuah tree dengan perkalian bobot sisi minimum. Maka spektrum bobot sisi dari $T$ dan $S$ tidak sama. Misalkan $k$ bobot sisi terkecil sehingga untuk semua sisi yang bobotnya lebih besar atau sama dengan $k$ maka $T$ dan $S$ mempuyai spektrum bobot sisi tidak sama. Akibatnya, dengan cara yang sama dengan sebelumnya, maka $S$ mempunyai lebih kecil atau sama banyaknya sisi yang bobotya $k$ dari pada $T$. Misalkan $S(k)$ adalah himpunan sisi $S$ yang bobotnya lebih kecil atau sama dengan $k$. Kemudian anggota $S(k)$ dapat dipilih semuanya dengan menggunakan algoritma kruskal. Karena spektrum dari sisi yang bobotnya $k$ belum digunakan semuanya, maka paling sedikit ada satu sisi $e \in G$ yang bobotnya $k$ tidak membentuk cycle dengan $S(k)$. Sisi $e$ yang demikian akan membentuk sebuah cycle dengan $S$. Karena itu, ada beberapa sisi pada cycle tersebut yang bobotnya lebih besar dari bobot $e$. Ganti sisi yang bobotnya lebih besar dari bobot $e$ dengan sisi $e$, sehingga diperoleh sebuah tree dengan perkalian bobot sisi lebih kecil dari perkalian bobot sisi $S$. Hal ini kontradiksi dengan hipotesis bahwa $S$ adalah perkalian bobot sisi minimum. Jadi jika $T$ mempunyai penjumlahan bobot sisi minimum, maka $T$ mempunyai perkalian bobot sisi minimum.

Teorema 3.2. [8] Misalkan $H$ adalah himpunan dari $n$-1 sisi dari graf $G$ dengan pembobotan, dan $M(H)$ adalah submatrik berukuran $(n-1) \times(n-1)$ dari A. Maka $H$ adalah sebuah minimum spanning tree jika dan hanya jika $|\operatorname{det} M(H)|$ adalah minimal diantara semua determinan submatriks non singular berukuran $(n-1) \times$ $(n-1) \operatorname{dari} A$.

Bukti. $(\Rightarrow)$ Misalkan $H$ adalah minimum spanning tree pada graf $G$. Maka $H$ mempunyai $n$ titik dan $n-1$ sisi dari $G$ dan $H$ mempunyai penjumlahan bobot sisi minimum. Menurut Teorema 4.1. maka $H$ mempunyai hasil perkalian bobot sisi minimum, ini berarti $|\operatorname{det} M(H)|$ adalah minimal diantara semua determinan submatriks non singular berukuran $(n-1) \times(n-1)$ dari $A$.

$(\Leftarrow)$ Misalkan $|\operatorname{det} M(H)|$ adalah minimal diantara semua determinan submatriks non singular berukuran $(n-1) \times(n-1)$ dari $A$. Ini berarti bahwa hasil perkalian 
bobot sisi dari $H$ adalah minimum. Menurut Teorema 4.1., maka $H$ juga mempunyai penjumlahan bobot sisi minimum. Dengan demikian $H$ adalah minimum spanning tree pada graf $G$.

\section{Kesimpulan}

Berdasarkan uraian pada tugas akhir ini, diperoleh bahwa spanning tree adalah subgraf yang determinannya tidak sama dengan nol. Jika $|\operatorname{det} M(H)|$ dari suatu spanning tree memiliki nilai terkecil dan penjumlahan bobot sisinya juga merupakan penjumlahan terkecil, maka spanning tree tersebut adalah minimum spanning tree.

Mencari minimum spanning tree dengan konstren lebih mempersingkat waktu karena tidak semua subgraf akan dicari nilai determinannya. Subgraf yang akan dicari nilai determinannya hanya subgraf yang memiliki sisi konstren.

\section{Daftar Pustaka}

[1] Anonim. Tanpa tahun. Permutasi dan Kombinasi. kuliah.imm.web.id,

[2] Anton, H. dan Rorres, C .1991. Ajabar Linear Elementer. Edisi Kelima. Erlangga, Jakarta.

[3] Bondy, J.A dan Murty, U.S.R. 1976. Graph Theory with Application. London: The Macmillan Press LTD.

[4] Deo, Narshing. 1986. Graph Theory with Application to Engineering and Computer Science. Prentice Hall. New Delhi.

[5] Frank Harary, Graph Theory, Addison-Wesly Publishing, London, 1969.

[6] Narwen. Suatu Metoda untuk Menentukan Semua Minimum Spanning Tree dalam Suatu Graf. Tesis S-2 Matematika. ITB. Bandung, 2002.

[7] Norman Biggs, Algebraic Graph Theory, $2^{\text {nd }}$ cd., Cambridge University Press, New York, 1993.

[8] Perrin Wright, Counting and Constructing Minimal Spanning Trees, Bulletin of the Institute of Combinatorics and Its Applications 21(1997),65 - 76.

[9] Tucker, Alan. 1943. Applied Combinatorics. Sixth Edition. Jhon Wiley and Sons, Inc. 